\title{
Fateful Triangles in Brazil: A Forum on Stuart Hall's The Fateful Triangle: Race, Ethnicity, Nation, Part II
}

\author{
Sharon A. Stanley* \\ João Nackle Urt** \\ Thiago Braz***
}

\begin{abstract}
Stuart Hall, a founding scholar in the Birmingham School of cultural studies and eminent theorist of ethnicity, identity and difference in the African diaspora, as well as a leading analyst of the cultural politics of the Thatcher and post-Thatcher years, delivered the W. E. B. Du Bois Lectures at Harvard University in 1994. In the lectures, published after a nearly quarter-century delay as The Fateful Triangle: Race, Ethnicity, Nation (2017), Hall advances the argument that race, at least in North Atlantic contexts, operates as a 'sliding signifier,' such that, even after the notion of a biological essence to race has been widely discredited, race-thinking nonetheless renews itself by essentializing other characteristics such as cultural difference. Substituting Michel Foucault's famous power-knowledge dyad with power-knowledge-difference, Hall argues that thinking through the fateful triangle of race, ethnicity and nation shows us how discursive systems attempt to deal with human difference. In 'Fateful Triangles in Brazil', Part II of Contexto Internacional's forum on The Fateful Triangle, three scholars work with and against Hall's arguments from the standpoint of racial politics in Brazil. Sharon Stanley argues that Hall's account of hybrid identity may encounter difficulties in the Brazilian context, where discourses of racial mixture have, in the name of racial democracy, supported anti-black racism. João Nackle Urt investigates the vexed histories of 'race,' 'ethnicity' and 'nation' in reference to indigenous peoples, particularly Brazilian Indians. Finally, Thiago Braz shows, from a perspective that draws on Afro-Brazilian thinkers, that emphasizing the contingency of becoming in the concept of diaspora may ignore the myriad ways by which Afro-diasporic Brazilians are marked as being black, and thus subject to violence and inequality. Part I of the forum - with contributions by Donna Jones, Kevin Bruyneel and William Garcia - critically examines the promise and potential problems of Hall's work from the context of North America and western Europe in the wake of \#BlackLivesMatter and Brexit.
\end{abstract}

Keywords: Stuart Hall; race and racism; ethnic identity; diaspora; Afro-Brazilians; indigenous peoples; Brazilian racial politics.

\footnotetext{
* University of Memphis, Memphis-TN, USA; sastanly@memphis.edu. ORCID iD 0000-0002-4450-7255.

** Federal University of Grande Dourados (UFGD), Dourados-MS, Brazil; joaourt@gmail.com. ORCID iD 0000-0002-7785-2450.

*** Pontifical Catholic University of Rio de Janeiro (PUC-Rio), Rio de Janeiro-RJ, Brazil; braz.thiago@gmail. com. ORCID iD 0000-0002-5658-0361.
} 


\section{Stuart Hall Against Stuart Hall}

Sharon A. Stanley

Stuart Hall's Du Bois Lectures, delivered at Harvard University in April 1994 and recently published as The Fateful Triangle: Race, Ethnicity, Nation (2017), pose a series of questions that haunt virtually any scholar who confronts the daunting complexity of racial identities and racial politics in the postcolonial world. Given the wide recognition that race has no biological or natural basis, why does our race talk nonetheless continue to bear the unmistakable marks of biologizing and naturalizing language? Is there some way to think about and talk about human difference that would definitively banish illegitimate biological presumptions? Would ethnicity, perhaps, make a fitting replacement for race? Through a dazzling analysis of race (and ethnicity) as a 'sliding signifier' and racial classification systems as 'discursive operations of meaning', Hall (2017: 64) provides us with a compelling way of understanding both the tenacity and the complexity of racial identities, and the inadequacy of simply replacing race talk with ethnicity talk. Yet I would like to suggest, by way of an engagement with racial politics in Brazil, that Hall's masterful theoretical apparatus for understanding what race is, and how it functions, complicates some of his own normative conclusions.

Let us begin with that theoretical apparatus. Hall (2017: 31) clarifies his understanding of discourse in the first lecture:

As we set out to ask what it means to rethink cultural difference in discursive terms, discourse should be understood as that which gives human practice and institutions meaning, that which enables us to make sense of the world, and hence that which makes human practices meaningful practices that belong to history precisely because they signify in the way they mark out human differences.

Inspired by poststructural theorists such as Michel Foucault and Jacques Derrida, Hall intends to cut across the dubious distinction between 'mere' ideas, expressed through language, and material practices, locating the power of the idea of race in the mutual constitution of these ostensibly distinct realms. Insofar as racial categories organize human practices, most importantly including practices of domination and subordination, and human practices in turn establish the 'truth' of these categories, investing them with enduring meaning, race cannot conveniently evaporate once its biological status has been convincingly rebutted. Such a task is made more difficult still by the fact that we read racial categories from visible characteristics that we cannot simply unsee - what Hall (2017: 39), via both Anthony Appiah (1985) and W.E.B. Du Bois (1970), refers to as the 'grosser physical differences of color, hair, and bone.' At the same time, discourse is always a site of struggle and contention. Signification constantly shifts and transmutes in unpredictable ways. This is true of specific racial categories and of the overarching category of race itself. 
It is this uncertainty, this impossibility to fix meaning once and for all, that Hall means to capture with the term sliding signifier. For example, Hall (2017: 63) notes that we take the physical features of black bodies as indications of an unseen genetic code, converting these features into signifiers of natural and biological essence: 'So what precisely tends to fix race in its obviousness and visibility - in physical characteristics of "color, hair, and bone" - are themselves nothing but signifiers of an invisible code that writes difference upon the black body'. Yet these features also come to signify something crucial 'further up the signifying chain, where they are correspondingly read as "true" when it comes to differences of culture, intellectual and cognitive capacity, emotional temperament, and social accomplishment' (Hall 2017: 64). We find a double uncertainty here: what is signified by these signifiers in the realms of nature and culture can be and frequently is contested, and what is signified by race itself slides between the biological and the cultural, with traces of the former inevitably haunting definitions that seek to locate race firmly in the realm of the latter.

Replacing race with ethnicity cannot save us from this dilemma. Ethnic identities often derive their power from a strong 'sense of place and of group origins' (Hall 2017: 107). When ethnicity becomes articulated in this manner with shared history, shared origins, and a sense of kinship and inheritance across countless generations, 'it is experienced and imagined by many not as a discursive construction but as having acquired the durability of nature itself' (Hall 2017: 107). Hall (2017: 108-109) subsequently explains:

Thus, whereas race is grounded in the biological and slides toward the cultural, ethnos or ethnicity in the strong sense that I've just described appears to be grounded exclusively in the cultural, in the realm of shared languages, specific customs, traditions, and beliefs, yet it constantly slides-especially through commonsense conceptions of kinship - toward a transcultural and even transcendental fix in common blood, inheritance, and ancestry, all of which gives ethnicity an originary foundation in nature that puts it beyond the reach of history.

Ethnicity and race essentially slide into each other, then. Ethnicity can acquire the durability of race through the naturalization of culture, and race can found categorical cultural differences often interpreted through the lens of a hierarchical scale from inferior, savage cultures to superior, civilized cultures. Ethnicity offers no refuge from the perils of race talk.

But Hall does, finally, find a potential refuge in the more flexible, diasporic ethnoracial identities produced by the migratory and cultural flows of contemporary globalization. These hybrid identities contrast markedly with closed, essentialist conceptions of race, ethnicity, and nation. Of course, the idea of diaspora can also imply timeless origins and cultural continuity, but Hall (2017: 164) calls on us instead to 'unsettle these patterns, and establish an alternative chain of equivalences, that the term diaspora begins to function as a signifier of translation across differences.' Sites of intense cultural contact 
demand 'neither the refusal of difference nor its hardening and fixing, but its constant and ongoing negotiation' (Hall 2017: 166). Unfortunately, the very challenge that such an orientation poses to more closed forms of ethnic, racial, and national identification provokes a defensive backlash that Hall associates with religious fundamentalism, virulent ethnic nationalism, and xenophobia - an account that seems darkly prophetic from the vantage point of 2019. Hence, the battle lines and their normative stakes are clearly drawn: flexible, hybrid cultural identities permanently remaking and reconceiving themselves, open to dialogue with and transformation through others, on the one hand, and closed, fundamentalist cultural identities on the other hand, positioned in a permanent defensive crouch against any and all threats to their purity.

In Hall's only scholarly visit to Brazil, to deliver the keynote lecture to the VII Congress of the Brazilian Association of Comparative Literature in Salvador in 2000, he chose the vantage point of the Caribbean to 'explore the particular problems of conceptualizing "culture", "power", identity and difference, hoping that this point of view would resonate in Brazil, and especially in Bahia (Hall 2016: 48). Here, again, he emphasizes the antithesis between conceptions of culture that rest on 'a fixed opposition between us and them, inside and outside' and 'the syncretized configurations of Caribbean culture' that 'seem to require Derrida's notion of différance' (Hall 2016: 51). He rightly warns that we must avoid a simplistic binary in which cultures fall neatly into one category or the other, in order to avoid 'fall[ing] backwards into a playful deconstructionism, the fantasy of a power-less utopia of difference' (Hall 2016: 52). Diasporic identities are always, he notes, 'haunted by a profound sense of "loss" (Hall 2016: 51). Yet I would like to suggest that Hall does not entirely heed his own warning. It is not that he forgets the brutal legacies of colonialism, slavery, and racialized exclusion that have produced diasporic identities, but rather that the normative opposition between open hybrid identities and closed binary identities fails to capture how this distinction itself has been politically deployed to obfuscate racism throughout the Americas, and especially in Brazil. Hall's account of race as a discursive sliding signifier proves a brilliant tool for excavating the vertiginous Brazilian racial landscape, but it also reveals the limits of his valorisation of flexible racial identities.

It has become virtually cliché to comment upon Brazil's dizzying variety of colour terms. Famously, in an open-ended 1976 survey (Brazilian Institute of Geography and Statistics 1999), respondents chose 134 distinct colour terms to describe themselves, including such creative terms as sapecada (burnished red), paraíba (like the color of marupa wood), and morena-cor-de-canela (cinnamon-hued brunette). (I have borrowed the English translations included in the excerpt; from here forward, all translations from Portuguese are my own.) This baroque colour vocabulary has sometimes been taken to indicate that 'race' simply does not function as a socially significant category in Brazilian life. For example, Demétrio Magnoli (2009: 146) writes: 'The dozens of creative expressions of those interviewed by the PNAD reflect the precariousness of racial identities in Brazil, and the valorisation of an intermediate identity, which is not essentially racial.' Yet careful study of how Brazilians use racial and colour categories reveal that bipolar (black vs. white) racial categories do function in everyday Brazilian discourse - alongside dozens of 
colour categories. For example, based on her ethnographic studies of the Rio de Janeiro favela Morro do Sangue Bom, Robin Sheriff (2001: 31) writes: 'I hope to demonstrate that both distinctions - that between description and classification and that between race and colour - are critical to an understanding of race in Brazil.' Indeed, a racial hierarchy that positions white on top and black on the bottom, with only quite minor and often insignificant differences between preto (black) and pardo (brown/mixed) clearly operates in Brazilian social, economic, and political life (Telles 2004). So race in Brazil slides from a fluid, unpredictable phenotypical descriptor rooted in colour to a more rigid, bipolar classification system rooted in imagined blood and biology, and both significations have material effects in Brazilian life. A better illustration of race as discursive sliding signifier would be difficult to find.

Brazil's countless intermediate colour terms are closely related to the longstanding myth of racial democracy. This myth, often attributed to Gilberto Freyre as its founder, holds that intense racial mixing or mestiçagem has created a hybrid 'brown' nation without categorical racial distinctions and therefore also without virulent forms of racism. As Freyre (1966: xii) himself put it: 'The absence of violent rancors due to race constitutes one of the peculiarities of the feudal system in the tropics.' It is here that the discursive functioning of race in Brazil, so aptly captured by Hall's account of race as a sliding signifier, begins to trouble Hall's normative distinction between syncretized and flexible racial identities, to be affirmed, and categorical racial distinctions that foster exclusion and hostility. Hall repeatedly associates this latter, nefarious type of racial identity with 'binary' racial thinking. For example, he urges us to investigate 'why these racial classificatory systems persist' and 'why so much of history has been organized within their primordial binaries' (Hall 2017: 43). Similarly, he claims that 'the discourse of racism operates in a world of Manichean opposites - them and us, primitive and civilized, light and dark - which creates a seductive black-and-white symbolic universe' (Hall 2017: 71). Hall (2017: 73) holds that this binary form seeks precisely to 'contain the sliding of the racial signifier.' This is why he finds hope in flexible diasporic identities - because they disrupt rigid binaries and find a way to live with, even embrace, the inevitable sliding of the racial signifier. Yet the Brazilian racial regime does not seem to fit into these normative parameters. Emphasizing the proliferation of colour terms rather than the enduring significance of bipolar black vs. white racial categories, some scholars have argued that the very idea of a 'black' identity in Brazil is a mirage of US cultural imperialism, a doomed imposition of rigid racial categories on a country where they have no foothold (Bourdieu and Wacquant 1999; Risério 2007). More explicit conservatives have embraced this argument, wedding a celebration of mixture, flexibility, impurity, and hybridity, and a bitter rejection of binary racial thinking, to a pernicious myth that Brazilian racism is less acute than US or South African racism and requires no systematic redress (Kamel 2006; Magnoli 2009).

Black Brazilian activists have accordingly seen the proliferation of Brazilian colour categories as an obstacle to racial justice. Instead, they advocate a shared Afro-descendant identity to forge greater solidarity and political efficacy: "We must not allow ourselves today to be divided into adverse categories of "Blacks" and "mulattoes," weakening our 
fundamental identity as Afro-Brazilians, Afro-Americans of all the continent, that is, Africans in the Diaspora' (do Nascimento 1980: 156). Accordingly, in advance of the 1990 census, black Brazilian organizations criticized the official categories of preto and pardo. In the absence of a new negro category that would encompass both categories, they mounted a campaign led by the Afro-Brazilian feminist activist Wania Sant'Anna to dissuade Afro-descendants from effectively whitening themselves by self-identifying as pardo or branco (Daniels 2006: 250; Nobles 2000: 152). The campaign's title, "Não deixe sua cor passar em branco: responda com bom c/senso" (Don’t let your colour pass into white: respond with good sense) relied on a pun between censo (census) and senso (sense). A negro identity cuts across Hall's central normative opposition. On the one hand, it is explicitly diasporic, providing a capacious and highly creolized understanding of blackness in Brazil. Yet as we have just seen, critics of this movement such as Antonio Risério view it as an attempt to erase the reality of mestiçagem from Brazilian life and to create precisely the sort of rigid racial binary that Hall himself criticizes:

I believe it is a futile effort to make blacks and whites, in Brazil, enclose themselves in castes like in the United States. Our mixtures have already endured too long - and our blending is deeply rooted. The development of a "black conscience" hasn't rendered people impermeable. We have been shaped as a people given to contacts and contagions. Everything tends to happen here in a non-linear way. To think the opposite is to be out of touch with the country (Risério 2007: 66).

Risério's language describing Brazilian mestiçagem often echoes Hall's descriptions of flexible diasporic identities. He rejects racial binarism and pays homage to syncretism, hybridity, plasticity, blurred boundaries, routes rather than roots. Yet his bitter opposition to the contemporary black movement in Brazil suggests an even more complicated discursive scene than the one Hall sketches in his Salvador keynote.

To be sure, Hall's own account of hybridity is not as naively celebratory as Brazil's prophets of racial democracy or their contemporary descendants. He carefully distinguishes hybridity as an always-unfinished process of negotiation and translation from hybridity as a permanently achieved, fixed state of particular societies or individuals:

The term hybridity is not a reference to the mixed racial composition of such societies: even those who seem able to trace a direct line of descent elsewhere are, in my view, culturally already significantly hybridized. Nor does the term refer to individuals, who can then be contrasted as fully-formed subjects with "traditional" or "modern" ones. Rather, it is another term for the process of cultural translation, an agonistic process since it is never settled and complete, but is always "in transition", in translation, marked by an ultimate undecidability. Hybridity is certainly not simply celebratory - even if as Salman Rushdie once remarked, it is also one of those impure routes 
by which "newness enters the world." It cannot be fully celebrated because it has deep and often disabling costs, drawing them - as James Clifford once observed - from its multiple forms of dislocation and habitation (Hall 2016: 50).

This reflection points us in the direction of a distinction between Hall's hybrid diasporic identities and the calcified 'mixed' identities of Brazil's racial democracy myth. Indeed, we find this distinction evoked by contemporary theorists of hybridity such as Deborah Kapchan and Pauline Strong (1999). Yet even emphasizing the unfinished and always-in-process character of Hall's preferred hybridity does not definitively answer the concerns that a view from Brazil raises. First, while the classical theorists of racial democracy such as Gilberto Freyre certainly do essentialize hybrid identities in precisely the way that Hall denounces, more sophisticated contemporary celebrations of mestiçagem, such as Risério's, avoid this trap and echo Hall in depicting Brazilian hybridity as an eternally unfinished process - all the while doubling down on the denunciation of Brazil's black movement as fundamentally un-Brazilian. Second, Hall's persistent conceptual opposition between racial 'binaries' and flexible, diasporic identities plays into these denunciations, insofar as attempts to forge a black identity in Brazil push Brazil toward a more binary system of racial classification. In addition to distinguishing normatively different modes of hybridity, then, we may also need to distinguish different modes of racial binarism.

So, we find ourselves in a bind as we bring Stuart Hall to Brazil. The very theoretical tools we have borrowed from him to analyse the discursive functioning of race in Brazil cast doubt on his depiction of the 'primordial binaries' of conventional race discourse and the flexible diasporic identities that have the potential to contest these pernicious binaries. The celebration of flexible identities and the condemnation of racial binarism in Brazil have been effectively employed as a discursive weapon of racial backlash striving to dismantle the limited gains of the black movement thus far, such as affirmative action in universities. Yet this is not a damning criticism of Hall. Quite the contrary, it is a testament to the strength of his theoretical vision that we can employ his own tools to complicate his normative conclusions. For if race is a discursive sliding signifier, then Hall would surely concur that the normative stakes and indeed the very meanings of particular accounts of race (binary vs. fluid; pure vs. hybrid; etc.) can never be settled once and for all. In pitting Stuart Hall against Stuart Hall in Brazil, the virtuosity and adaptability of his account of race, ethnicity, and nation paradoxically become all the more apparent. 


\section{Indigenous peoples: race, ethnicity, nation?}

Let me depart from two premises. First, colonies, by installing an armed peace between the settlers/colonizers and the colonized, are either the continuation of the war of conquest by other means or their metonymic substitution (see Urt 2015). Second, colonies remain the current structure underlying Indigenous peoples' socio-political relations in the contemporary world. Maybe evident for some and bizarre for others, I take those statements as my point of departure, for I would like to bring the fact that Indigenous peoples currently live with the roughness of colonization, as a permanent state of affairs, in order to help put Stuart Hall's discussion into perspective. These are the lenses under which - as a white settler researcher of Indigenous politics who has lived for some years in the colonial situations secularly installed over Indigenous territories in Brazil - I invite the reader to assess Hall's ideas. The need for constant resistance from Indigenous peoples brings to the fore that the discussion advanced in The Fateful Triangle presents risks and perils: renewed interpretations may result in further denial of rights (already contested and menaced) and the actual deterioration of their lives.

The consideration of those risks requires a work of translation, from the context of Afro-Caribbean migrations to post-war Great Britain to the many contexts of Indigenous peoples in the contemporary world. As Hall (2017: 98) himself stated:

What we have here, then, is an emergent field of racial, cultural, and ethnic difference and contestation in the late twentieth century that is articulated in different ways in different places. I would define this as a proliferating and fragmenting field of antagonism and cultural contestation that refuses to become a unified and sutured space of political representation, instead remaining a field of difference articulated in its relatively dislocated and disaggregated form as a site of generalized antagonism.

How do we address the complexities of such a field which, with the inclusion of Indigenous peoples, mirrors a yet more proliferating and fragmenting reality? In what sense can race, ethnicity and nation be useful keys to Indigenous peoples' comprehension of today's world and to the advancement of their struggles?

Hall (2017: 86) recognizes that 'the relationship between race and ethnicity remains troubled and problematic.' With regard to that relationship, a crucial fact has been pointed out by Jodi Byrd: the racialization of Indigenous peoples, in academic and socio-political contexts, trumps the acknowledgment of the international character of their legal personalities.

This presumed self-evidentiary process of minoritization, of making racial what is international, continues to infect competing un- 
derstandings of citizenship, identity, inclusion, and exclusion with, among, and outside the intersections of sovereignty, race, land, and labor (Byrd 2011: 125-126).

Indeed, no matter how violated their collective political rights have been, peoples are sovereigns. It does not mean that they are sovereigns in the same way as states are. Indigenous sovereignties do not correspond to Westphalian, state-based sovereignties, and they should not (see Alfred 2001). And recognizing Indigenous sovereignties is not meant to defend the inclusion of Indigenous peoples into the international system (actually a Eurocentric system of states). On the contrary, while asserting their radical alterity, it can serve at least three purposes: to unsettle the meanings and legitimacies of Westphalian politics; to remember the authorities of Indigenous polities and their leaderships, despite the occlusion thereof; and, above all, to affirm their freedom, as collectivities, to take their own paths for the future. (Occlusion is 'the practice of limiting an existing and legitimate sovereignty to the point where it presents the appearance of a non-sovereignty' (Urt 2016: 866).)

Nevertheless, discourses in which race is considered a major identifier (even anti-racist discourses) often neglect Indigenous peoples' political precedence in the colonized territories. Byrd exemplifies such a feature with a critique of the work of bell hooks (1995):

By identifying slavery as the original sin of the United States' colonialist project, bell hooks is able to foreground how racism continues to perpetuate the economic, social, and political oppressions African Americans face every day within the United States, but in the process she perpetuates the colonialist narratives that deny the land ever belonged to anyone prior to the United States (Byrd 2011: 133-134).

Racial discourses equate Indigenous peoples to migrant minorities 'with no prior claim to nation or territory' (Byrd 2011: 126). In at least one passage, Hall (2017: 86) proceeds similarly to hooks, although implicitly: 'actual relations between blacks and ethnic minorities in the United States (and increasingly in Europe, east and west) [are] difficult socially and politically, a source of friction and trouble as often as they are a site of alliance and common cause.' Thus phrased, Indigenous peoples could only fit the category of 'ethnic minorities.'

Race and ethnicity therefore hamper the recognition of Indigenous societies as nations or peoples, as most Indigenous groups rightfully see themselves worldwide. (Whereas 'nation' has been claimed by most Indigenous peoples speaking English, 'people' has been the preferential word of choice by Indigenous societies speaking Portuguese and Spanish.) In addition, the treatment of nation as an exclusive product of statecraft, following Eric Hobsbawm's and Benedict Anderson's (1991) lineage, further forecloses the access of Indigenous peoples to collective political personality in global politics. The difference between 'American nation' and 'Cherokee nation' seems to me more of degree of power than of quality. I had such an impression when I realized that Darcy Ribeiro (1995), de- 
scribed Brazilianness as a macro-ethnicity. And Hall (2017: 144) puts it in similar terms: Englishness is not an ethnicity in its own (colonial) worldview, but it is the norm against which, by angle of deviation, ethnicity is to be measured.' Nations, in that sense of an attribute exclusive of states, create for themselves images that 'work discursively to secure difference so as to explain above all, why the natural rights of freeborn Englishmen were not appropriate for emancipated slaves, or for women for that matter, or for Aborigines, or Hindus, or Hottentots, or Maoris, or Zulus' (Hall 2017: 145).

Hall (2017: 137) is well aware that 'such discursive operations in the making of national culture identities are always, of course, closely articulated to power and the way power functions in society. 'Then, of course, nation is articulated in ways that exclude Indigenous societies as equal nations, as much as exclude Indigenous individuals as equal citizens. The same happens to people, which in basic political science is treated as one of the essential elements of the state, in a way that precludes Indigenous peoples from being recognized as collective historical subjects. Indeed, when 'people' is claimed by Indigenous peoples, it is with the intention of renovating such political grammar:

So, what is a people? A people is the project of being a history. When the history that weaves collectively, like the pattern of a tapestry where the threads design figures, sometimes approaching and converging, sometimes distancing themselves and in opposition, is intercepted, interrupted by force of an external intervention, this collective subject will try to take up the threads, make small knots, suture the memory, and continue on. In that case, there takes place what we could call a return of history, a restitution of the ability to plot its own historical path, resuming the drawing of the interrupted figures, weaving them to the present warp, projecting them towards the future (Segato 2013: 97, my translation).

The lack of attributing nationhood to Indigenous peoples, or of recognizing peoplehood as a category to give intelligibility to global modernity, further obscures the fact that Indigenous peoples do not live in postcolonial times.

With that major fact in mind, two other considerations emerge from the reading of Hall's work, that might rehabilitate race for an Indigenous vocabulary.

First, Hall's understanding of race seems useful for Indigenous peoples, just as it serves people of African descent, insofar as 'Indian' became as much a 'badge of identification' as 'black' did: 'a discursive political identity' across different ethnic groups (Hall 2017: 94). As a category, the 'Indigenous,' as well as the now less politically correct synonym 'Indian,' was created and imposed both as one of the conditions for the possibility of European sovereignty and as a means aimed at occluding the political sovereignties of the conquered peoples (Pratt 2007: 398-399; Urt 2016, 2015: 52-54). Yet, after secular resistance, Indigenous peoples have promoted a transnational process of ethnogenesis in the late twentieth century, thereby constituting a global Indigenous identity (Wilmer 1993) in complete disregard to any biological meaning of race: Native American, black, Asian, and even white 
societies have worn this badge. Just as 'the shared history of [past British] colonization and imperialism' (Hall 2017: 97) contributed to uniting Asians and Afro-Caribbeans around 'black', the shared narratives of present oppression under contemporary colonization have tended to unite Indigenous peoples. One difference is that an Indigenous transnational movement has both struggled for and been stimulated by the international recognition of specific human rights for Indigenous peoples (see De La Cadena and Starn 2007).

At a different scale, a similar typically racial dynamic has happened. Gersem Baniwa (2006: 30, my translation) explains that native peoples in Brazil have legitimately adopted the 'Indian' as a political signifier:

With the emergence of the organized indigenous movement from the 1970s on, the indigenous peoples in Brazil came to the conclusion that it was important to maintain, accept and promote the generic name of Indian or indigenous, as an identity that unites, articulates, visibilizes and strengthens all the peoples originating in what presently constitutes the Brazilian territory and, especially, to demarcate the ethnic and identitary frontier between them, as originary and native inhabitants of these lands, and those originary from other continents, such as Europeans, Africans and Asians.

One important difference, as underlined by Baniwa, is that Indian or Indigenous as race provides a badge, above all, to stand out from other racial groups, to affirm the unique character of Indigenous political claims and rights, arising from their 'prior-ity in time and place' (Pratt 2007: 398).

Finally, by framing race, ethnicity and nation as 'sliding signifiers', Hall helps rethink the process by which ethnology, aware of its close relationship to state-bureaucratic indigenism, promoted an updated form of knowledge by changing from the use of race to culture, and, more recently, ethnicity.

As is known, in the early days of the social sciences, the various manifestations of the anthropos were described within a racial model. Influenced by evolutionism, early anthropologists were (deliberately or not) at the service of understanding colonized peoples and, it was hoped, providing techniques to make the colonial enterprise more efficient and profitable. Anthropology's first language, similarly to the prevailing knowledges inherited from the prior centuries of colonization, was that of race, which facilitated the creation of scales of superiority and inferiority. 'Indian' was then a biological, racial category.

After World War II, in an effort to suit the social sciences to post-Holocaust times, the criterion that replaced race was that of culture. According to Manuela da Cunha, 'the cultural criterion [was] relatively satisfactory, insofar as it correspond[ed] to many of the empirical situations encountered' but was soon misused (2009: 250, my translation). 'Indian' became a category determined according to the observation of some cultural traits, no matter how ancient and intense was the ethnic friction inherent to colonization. Since it could be pointed out by external observers, culture became a ruler that allowed indigenist bureaucracies to tell who was and who was not Indigenous. 
Hence the academic social sciences took a step forward. The contribution of Frederik Barth prompted the passage from the culturalist paradigm to the ethnicist paradigm. According to Barth (1969: 13), ethnic groups are a form of social organization whose fundamental feature is 'the characteristic of self-ascription [or] ascription by others': 'To the extent that actors use ethnic identities to categorize themselves and others for purposes of interaction, they form ethnic groups in this organizational sense' (Barth 1969: 13-14). Culture is not the main feature that characterizes the ethnic group:

[T] he elements of the present culture of that ethnic group have not sprung from the particular set that constituted the group's culture at a previous time, whereas the group has a continual organizational existence with boundaries (criteria of membership) that despite modifications have marked off a continuing unit (Barth 1969: 38).

In short: culture changes; ethnic groups, as organizational realities, persist. Cultural change is a normal consequence of ethnic interaction and can even be used as a survival strategy:

$[\ldots]$ in terms of a theory of interethnic relations, phenomena such as the 'fluctuations' of ethnic identity - thanks to the possibilities open to its manipulation - and the exercise of (ethnic) identification must be interpreted as the often dramatic effort of the individual and the group to achieve their social survival (Cardoso de Oliveira 1976: 25, my translation).

Barth demonstrated that the cultural criterion was not sufficient and sometimes not adequate to define Indigenous peoples. Indigenous peoples started being understood as political collectivities that employ ever-changing cultures as social markers. This process reflected the commitment of anthropology to self-criticism and the perception that its language had political implications for the relationship between Indigenous peoples and colonizer states. I bring the historical narrative above with the intention of adding a variable to understand why race was gradually abandoned in the vocabulary of Indigenous politics, in favour of ethnicity. Not only had it been appropriated by other colonized groups in ways that did not fit Indigenous interests, but also race was perceived as a politically outdated concept, sometimes used in explicitly racist ways.

Still, this political-linguistic process did not eliminate 'what Ernesto Laclau calls the "chain of equivalences" between nature and culture that thus makes race function discursively as a system of representation' (Hall 2017: 57). Or, as Hall (2017: 154) states: 'emphasis on cultural belonging does not silence the biological, and certainly does not eliminate the genetic-physical signifiers of racial difference and their discursive effects.'

What it indicates, though, is that the signification of 'race,' 'ethnicity' and 'nation' have taken at least two different paths. In one of the branches of the bifurcation, both Indigenous leaders' word choices and ethnologists' theoretical praxis have refused race, for all the practical inconveniences it has presented in the struggle for Indigenous rights. On 
the other branch lies the necessity to give intelligibility to a world-system based on the coloniality of power: a model established upon the 'the social classification of the world's population around the idea of race, a mental construction that expresses the basic experience of colonial domination and pervades the more important dimensions of global power, including its specific rationality: Eurocentrism' (Quijano 2000: 533). Or, in Hall's (2017: 82) formulation, the discourse of race is 'a historically specific, particularly vicious and virulent manifestation within that larger discursive formation of cultural difference that we may call Eurocentrism or Western-centrism.' Hall contributes to affirm that both meanings are relevant for Indigenous politics.

Although anthropologists and Indigenous leaders intend to free themselves from the inconveniences of race, they may take advantage from the awareness of the sliding potential of such signifier.

Thinking about indigeneity from the reading of Stuart Hall's work is an endless puzzle. Many works in anthropology could help put it in perspective or subject it to criticism (De la Cadena and Starn (2007) being just one great example). From where I see, despite the fact that race presents limitations for understanding Indigenous peoples' contemporary conditions, Hall teaches it is not wise to completely disregard it. Race, as a biological concept, might still be a fiction, but it does constitute ourselves and our societies, either settler or colonized.

\section{Afro-diasporic connections: beyond the dialogues of otherness}

Thiago Braz

The discursive-genealogical intervention that Hall undertakes notably into the race-ethnicity-nation chain of signifiers that structure the field of political, economic, cultural and epistemic (im)possibilities in the modern-colonial contexts of the Black Atlantic, offers us potential pathways beyond the conventional constructivist routes and foundationalist shortcuts of our time. With an attentive eye on the conjunctural moments in which these signifiers slip and slide to find more often than not new grounds on the very same 'biologically' or otherwise fixed terrain in ways that reinforce the boundaries and hierarchies of our humanities, Hall looked to the African diaspora in search for the open-ended, contingent sites in which the proliferation of new subject positions potentially pose challenges on Westernized time-space configurations. In other words, his objective was precisely to shed light to these spaces of production and affirmation of differences in their capacity to disrupt the bounds and bonds of the fateful triangle of race, ethnicity and nation. In the lines that follow, while appreciating Hall's fine reading of historical conjunctures and his conceptual contribution to the study of racial dynamics, I set out to ponder over the risks of taking his work for a sort of diasporic theory of race capable of accounting for other Afro-diasporic localities beyond its historical and geographical field of dispute. In this 
sense, my reflection will center more on the possibilities of expanding the dialogue to other peripheral localities than more strictly on the merits and value of Hall's contribution. In the light of another Afro-diasporic context, such as a Brazil, the following question shall orient this short essay: how is a proposal centered on difference (or différance), contingency, multiaccentuality (multiple caption points) to enable us to politically and epistemically read and remake the terms that persistently organize the world through the universal/ particular binary structure of modernity-coloniality? Far from rehearsing a final answer to this question, this short essay seeks to take this reflection rather as an opportunity to assess the limits and potential of the agenda of postcolonial theory in illuminating global contexts, according to Hall's contribution to the field. In addition, I make the case for a primary exercise in sociohistorical localization in ways that might shed fresh light on possibilities for the affirmation of becoming over being, which in a sense summarizes Hall's underlying concern with dynamics of identity formations.

Situated within a scholarly tradition that frames the slavocratic modern-colonial project in terms of a play of signifiers of identity and difference, Hall's work sets out to unsettle an always already 'loose' and yet no less 'lethal "chain of equivalences"' (Gates 2017: xi) of cultural difference, notably by means of a discursive-genealogical method that permits one to unveil the articulatory practices within systems of meaning that authoritatively define the terms of cultural identity/difference and, in so doing, materially assigns the places and non-places, the centres and the margins, temporalities and fixity to the human condition. His proposal not being circumscribed to an exclusively formal, semiotic, and textual reworking of politico-cultural categories - insofar as his point of departure is that racism as a system of meaning - 'a way of organizing and meaningfully classifying the world' (Hall 2017: 33) has all too real effects - Hall departs from discursive constructionism toward attending more closely to the materiality of discourse. To this end, his proposal combines the postcolonial dialogues of otherness with contributions from Foucault's views on materiality and Derridean philosophy, among other conceptual tools drawn from poststructuralist scholarship, with which he derives a theoretical setup that permits him to move away from essentialist notions grounded in biology or static space-time configurations. In so doing, Hall is able to centre the analytical lenses on 'what matters historically [which are] the meanings that organize and are inscribed within the practices and operations of relations of power between groups' (Hall 2017: 47). In these ways, the idea of a sliding signifier is compelling in that it invites us to read contextually 'the interplay between the representation of difference, the production of knowledge, and the inscription of power on the body [in] a threefold relationship that is critical to the production of race' (Hall 2017: 47-8). In this sense, Hall also makes a contribution to the poststructuralist scholarship notably by adding the term difference to the binomial of power-knowledge, thus broadening the field of vision to examine racial dynamics.

Being, in Henry Louis Gates, Jr's (2017: xv) words, a soulmate of Gramsci's, one could probably say that Hall viewed the movements of diaspora cultures not only with the 'pessimism of the intellect' but also with a great degree of 'optimism of the will.' In the context of mass migration at a world scale, particularly from the peripheries to the centres of the 
world at the outset of 'globalization, Hall envisaged the possibilities of uprooting 'a certain conception of homogenous national cultural identity' and 'the whole notion of "one people, one ethnos, under one political roof"' (Hall 2017: 148). In this attempt, it must be noted, Hall sought to experiment with pathways beyond, on the one hand, liberalism and Marxism, as Janus-faced forms of Enlightenment narratives premised upon universalist narratives of progress. On the other hand, he also sought to distance himself from stronghold signifiers grounded in naturalist notions from which to derive a secured, predefined subject position. Obviously, in examining new identities, or rather new processes of identification in the context of worldwide migration he did not downplay the various attempts being made to subsume these, in his words, multiculturalizing and hybridizing dynamics into the dialectics of late modernity. In his perspective, the notion of diaspora is precisely a metaphor for the discursive production of interstitial spaces where, under conditions of transculturation, understood as the mutual transformation of different cultures, processes of hybridization, creolization and syncretism take place, calling for constant negotiation of the very terms of difference (Hall 2017: 164-166). In this sense, diasporas are framed as symptomatic of the consequences of the dialectics of early and late modernity and, simultaneously, the corporeal displacement, the symbolic deferral, and the space-time differentials within and beyond modern subjectivities. Drawing from Derrida, Halls sees the diaspora as constituted by similarity and difference.

As far as the politics he foregrounds, in contrast with a politics of difference which is articulated around closed, fixed constructions of cultural identity, diasporic cultures of difference are premised upon a politics of différance that disrupts the 'settled contours of race, ethnos, and nation' toward 'a multidimensional structure of similarities and difference - "a weave of differences" - which generates the contemporary politics of identity and differences as a field of positionalities' (Hall 2017: 172, emphasis in original). It must be noted that Hall had in mind critical junctures such as the moment in the 1970s when Afro-Caribbean youth who identified themselves as 'blacks' drew from the symbolism of Rastafarianism and the identification built around the symbolic homelands of Caribbean and Africa. In Hall's view, this politico-cultural articulation transformed and further deepened the content of black as a signifier, thus paving the way for new alliances in antiracist struggles and new subject positions (Hall 2017: 94). Central to Hall's proposal was envisaging ways for political articulation toward building novel and durable alliances. As Gates (2017) suggests in the foreword, one might have a better understanding of his politics by attending to all of his writing projects, including those concerned with grasping conservative politics, such as Policing the Crisis, published in 1978, and at same time deriving pathways toward the renewal of left politics - The Hard Road to Renewal, published in 1988. These projects should not be seen as dissociated from his work on race and culture. These different fields of dispute connect precisely at the point of a lifelong effort at foregrounding cultural practices of political articulation along the lines of race, class, and gender. Hence his work should not be read as a mere celebration of hyphened ethnicities and cultural differences. 
That being said, there are some considerations I would like to advance in connection with the particular project of postcolonial scholarship that centres on the so-called 'encounter' of the West and its 'Other' to derive theories of self/other, identity/difference from it. To the extent that this is central to Hallsian theoretical proposal of diasporic cultures of difference, it is important to heed the ways in which it might not quite speak to other Afro-diasporic contexts, at least not in the interest of building, in Hallsian lexicon, counter-hegemonic links (Hall 1990). As the guiding question above suggests, there is a way in which framing racial dynamics in terms of a problem of difference tends to divert our attention from the processes and mechanisms through which norms, standards, and pacts of a white patriarchal supremacy, coded by the European slavocratic modern-colonial project and secured by its army of binaries, authorize and qualify those situated at the privileged ranks. These are critical processes that need to be scrutinized in context and unpacked since they are the key to the constant displacement and reconfiguration of the colour lines that define our (im)possibilities of our (co)habitation. The persistent formulation of racial dynamics in terms of problems of difference, in ways that leave the 'mythical norm' (Lorde 1984: 116) and its social engineering machine unassessed, inevitably leads to axiomatic thinking, as we see Hall's antifoundationalist move ultimately leaning towards Bakhtinian and Levinasian approaches to a sort of ethics of alterity (Hall 2017: 129). As Audre Lorde (1984: 116) makes clear, 'the mythical norm is usually defined as white, thin, male, young, heterosexual, Christian, and financially secure.' And it is with this norm that the trappings of power lie within postcolonial societies. In addition, as Hall himself was all too well aware, claiming multiple subject positions in the affirmation of difference does not amount to enjoying the humanized and dignified spaces to experience and express that subjectivity. These discourses on ethics of alterity tend to lose sight of the infrastructural conditions - psychological, cultural, economic, social elements - necessary for the enunciation of a new subject position to amount to actualizing that longed-for humanized and dignified space of cultural expression.

Stronghold concepts such as race and gender, among other relational categories, do provide us with the analytical lenses with which to read and respond to imbricated dynamics of power set by hardwire systems of domination, namely racism/sexism, that organize the postcolonial societies that we have inherited. By properly ridding of the modern-colonial dichotomy of nature/culture that has animated poststructuralist, postcolonial/decolonial debates over how to work with the categories of race, gender, class and sexuality in the context of anti-racist and anti-sexist struggles (Collins 1993; Gonzalez 1988; Vigoya 2008; Oyewumi 2000; Curiel 2014), one should caution not to throw the baby out with the bath water. Race and gender/sexuality are stronghold concepts deriving from systems of domination that define the field of (im)possibilities of our being in the slavocratic modern-colonial world.

In postcolonial contexts such as in the territory of Brazil, notions of hybridity, syncretism, morenidade (a creolized identity) were part and parcel of the discursive regimes produced by whitened patriarchal elites so as to claim a differentiated position for Brazil in the 1930s world stage. Far from opening up the field of positionalities and fostering 
new articulations of the social, these enunciations served precisely, in Hallsian lexicon, as caption points operating in assimilationist logic within a racist system of meaning that thwarted notions of race/racism, which determined along color lines the life/death conditions of peoples within the bounds of Brazilian territory. These discursive practices produced the effect of effacing or blurring from the signifying field the contribution of the peoples of African and indigenous descent in the constitution of Brazil. In effort to mirror European markers of civility, postcolonial elites sought to (re)code the elements of Afro-diasporic culture onto the grammar of nationality, which deprives these cultural elements of their cosmovision and genealogical underpinnings, whilst also casting upon them the veil of the eurocentred category of popular culture, and assigning them to the exoticized and commodified space of folklore (Gonzalez 2018) within national culture.

Within the discourse of racial democracy that still reverberates and informs the Brazilian imago, Afro-diasporic intellectuals like Lélia Gonzalez (2018) and Abdias do Nascimento (2016) draw our attention to the fact that religious and cultural syncretism experienced in Brazil, particularly in terms of the fusion of beliefs from European, African and indigenous traditions, sought to conceal the systematic attempts by the Brazilian state to domesticate, persecute and criminalize African and indigenous religions and cultures. By the same token, the articulation of a Brazilian modern nationality in term of a mestiço/ moreno identity cast a veil upon the past and current multifaceted forms of genocides and epistemicides that victimize the peoples of African and indigenous descent.

It is precisely this Latin and Iberian amalgamation of miscegenation, assimilation, and the ideology of whitening, as brutal weapons of white supremacy, that Lélia Gonzalez (1988b: 72) termed a racism of denegation - a system that articulated a discourse of racial democracy in the context of structured and structuring violences and extreme inequalities that mark the Brazilian society. Lélia Gonzalez (1988b: 72) sets the Latin Iberian modern-colonial project in contrast with Anglo-Saxon, Germanic or Dutch supremacist models through which notions of purity and separate but equal discourses and practice fostered the kinds of organization exemplified by South African or US segregation systems.

At stake in these attempts by the Brazilian state invested in the role of, as Hall would say, cultural broker is the repression and erasure of the cultural, linguistic, political contributions of the peoples of African and indigenous descent in ways that preclude them from access to their cultural roots. On the flipside, the governing broker leads systematic forays into public spheres so as to efface race/racism as signifiers, thus constraining the possibilities of naming and bringing racial dynamics to the politico-institutional table of disputes. In addition, to the extent that Afro-diasporic subjects remain imbibed in the ideology of whitening, there remain few possibilities to move to what Kobena Mercer (2017: 8) calls 'the polycentric networks of cross-cultural routes' in his characterization of the Black Atlantic model. 'Diaspora identities,' Hall (1993: 362, cited in Hall 2017: 174) himself notes, 'move into the future through a symbolic detour through the past. [This] produces new subjects who bear the traces of the specific discourses which not only formed them but enable them to produce themselves anew and differently'. What is implied in Hall's passage above is that without inhabiting 'the roots' - here taken notably for a metaphor of tradition 
- as pathway to restitution, memory, redistribution, the odds of attaining these (trans) cultural routes towards autonomy, self-determination and dignified forms of existence remain low.

Significantly, this raises a set of question relating to the language with which to access, reclaim and (re)constitute tradition and, most fundamentally, the issue of building the infrastructural conditions necessary to produce novel (trans)cultural systems of meaning organized in terms other than upon the racial hierarchization of our humanities. It is my argument that the possibility of (re)creating such system of meaning and of setting off on the pathways towards new forms of being, towards becoming, hinges on our capacity to ask the primary question of 'where we are' and 'where is today'. This primordial task of political and historical localization is pivotal for us to defer the foreclosure of modern-colonial binomial of self/other with its Janus-faced humanistic and narcissistic quandaries.

In addition, it is my understanding that jumping straight to ascribing precedence to becoming over being before asking these questions that help us put ourselves in context tends to frame these political issues - in the ultimate analysis, concerning the conditions of possibilities of experimenting with human existence in affirmative and autonomous terms - in moral terms, as primarily ethical issues. The same might happen when racism is framed in terms of a question of an encounter with alterity in the kinds of dialogues of otherness that characterize most of the postcolonial scholarship (see Mbembe 2018). Besides the sorts of precedence ascribed to ethics as a response to historico-political issues that map into long debates in political theory and theories of justice, the implication of this is that, insofar as we do not cultivate a responsibility to read how relational categories of power such as race, gender, sexuality, among others, interpellate us on a daily basis and hence inform in every situations our conditions of possibilities for knowledge, power and being in nature, it will be impossible to implicate ourselves in the extremely important dynamics of cultural politics. As Hall (2017: 130, emphasis in original) alerts us, 'cultural identities matter not because they fix us into place politically, but because they are what is at stake - what is won or lost - in cultural politics.' I should add that raising self-awareness to the forces at play in each situation, context, and the politics of positioning required from each and every one from his/her place shall also illuminate who benefits from, and who bears the costs of, the responses that we rehearse.

\section{References}

Alfred, Taiaike. 2001. 'From Sovereignty to Freedom: Towards an Indigenous Political Discourse.' Indigenous Affairs 3: 23-34.

Anderson, Benedict. 1991. Imagined Communities: Reflections on the Origin and Spread of Nationalism. New York: Verso Books.

Appiah, Anthony. 1985. 'The Uncompleted Argument: Du Bois and the Illusion of Race.' Critical Inquiry 12 (1): 21-37.

Baniwa, Gersem dos Santos Luciano. 2006. O Índio Brasileiro: o que você precisa saber sobre os povos indígenas no Brasil de hoje. Brasília: Ministério da Educação, Secretaria de Educação Continuada, Alfabetização e Diversidade; LACED/Museu Nacional. 
Barth, Frederik. 1969. 'Introduction.' In Fredrik Barth (ed), Ethnic Groups and Boundaries: The Social Organization of Culture DifferenceBoston: Little, Brown \& Company, pp. 9-38.

Bourdieu, Pierre and Loïc Wacquant. 1999. 'On the Cunning of Imperial Reason.' Theory, Culture \& Society 16 (1): 41-58.

Brazilian Institute of Geography and Statistics. 1999. 'What Color Are You?' In Robert M Levine and John J Crocitti (eds), The Brazil Reader: History, Culture, Politics. Durham: Duke University Press, pp. 386-390.

Byrd, Jodi A. 2011. The Transit of Empire: Indigenous Critiques of Colonialism. Minneapolis: University of Minnesota Press.

Cadena, Marisol de la and Orin Starn (eds). 2007. Indigenous Experience Today. Oxford: Berg.

Cardoso de Oliveira, Roberto. 1976. Do índio ao bugre: O processo de assimilação dos Terêna. 2nd ed. Rio de Janeiro: Livraria Francisco Alves Editora.

Collins, Patricia H. 1993. 'Toward a new vision: race, class and gender as categories of analysis and connection.' Race, Gender \& Class 1 (1): 25-45.

Cunha, Manuela Carneiro da. 2009. Cultura com aspas e outros ensaios. São Paulo: Cosac \& Naify.

Curiel, Ochy. 2014. Género, raza, sexualidad: debates contemporáneos. Colombia: Universidad del Rosario. At http://www.urosario.edu.co/urosario_files/1f/1f1d1951-0f7e-43ff-819f-dd05e5fed03c [Acessed on 25 February 2019].

Daniels, G Reginald. 2006. Race and Multiraciality in Brazil and the United States: Converging Paths? University Park: Pennsylvania State University Press.

Du Bois, W. E. B. 1970. 'The Conservation of Races'. In Philip S. Foner (ed), W.E.B. Du Bois Speaks: Speeches and Addresses, 1890-1919, Vol. 1. New York: Pathfinder Press, pp. 83-95.

Freyre, Gilberto. 1966. The Masters and the Slaves: A Study in the Development of Brazilian Civilization. Translated by Samuel Putnam. 2nd ed. New York: Albert A. Knopf.

Gonzalez, Lélia. 1988. 'Por um feminismo afrolatinoamericano.' Isis Internacional 9: 133-141. 1988b. 'A categoria político-cultural de amefricanidade.' Tempo Brasileiro 92/93. 2018. Primavera para as rosas negras: Lélia González, em primeira pessoa. São Paulo: UCPA. Hall, Stuart. 1993. 'Culture, Community, Nation.' Cultural Studies 7 (3): 349-363.

1990. The Hard Road to Renewal: Thatcherism and the Crisis of the Left. London/New York: Verso.

. 2016. 'Diasporas, or the logics of cultural translation.' MATRIZes 10 (3): 47-58.

2017. The Fateful Triangle: Race, Ethnicity, Nation. Edited by Kobena Mercer. Cambridge: Harvard University Press.

Hobsbawm, E J. 2012. Nations and Nationalism since 1780: Myth, Programme, Reality. 2nd ed. Cambridge: Cambridge University Press.

hooks, bell. 1995. Killing Rage: Ending Racism. New York: Henry Holt.

Kamel, Ali. 2006. Não somos racistas: uma reação aos que querem nos transformar numa nação bicolor. Rio de Janeiro: Editora Nova Fronteira.

Kapchan, Deborah and Pauline Turner Strong. 1999. 'Theorizing the Hybrid.' Journal of American Folklore 112 (445): 239-253. 
Lorde, Audre. 1984. Sister Outsider: essays and speeches. Freedom: Crossing Press.

Magnoli, Demétrio. 2009. Uma Gota de Sangue: História do Pensamento Racial. São Paulo: Contexto. Mbembe, Achille. 2018. Africa é a última fronteira do capitalismo. Interview by Antonio Guerreiro. At https://www.publico.pt/2018/12/09/mundo/entrevista/africa-ultima-fronteira-capitalismo-1853532\#gs.5OXaTnc8 [Accessed on 25 February 2019].

Nascimento, Abdias do. 1980. 'Quilombismo: An Afro-Brazilian Political Alternative.' Journal of Black Studies 11 (2): 141-178.

2016. O Genocídio do Negro Brasileiro: Processo de um Racismo Mascarado. São Paulo: Perspectiva.

Nobles, Melissa. 2000. Shades of Citizenship: Race and the Census in Modern Politics. Palo Alto: Stanford University Press.

Oyèwúmi, Oyèronké. 2000. 'Family bonds/conceptual binds: African notes on Feminist Epistemologies.' Signs 25 (4): 1093-1098.

Pratt, Marie Louise. 2007. 'Afterword: Indigeity Today'. In M de la Cadena (ed), Indigenous Experience Today. Oxford: Berg, p. 397-404.

Quijano, Aníbal. 2000. 'Coloniality of Power, Eurocentrism, and Latin America.' Nepantla: Views from South 1 (3): 533-580.

Ribeiro, Darcy. 1995. O povo brasileiro. Rio de Janeiro: Companhia das Letras.

Risério, Antonio. 2007. A Utopia Brasileira e os Movimentos Negros. São Paulo: Editora.

Segato, Rita. 2013. La crítica de la colonialidad en ocho ensayos y una Antropología por demanda. Buens Aires: Prometeo Libros.

Sheriff, Robin E. 2001. Dreaming Equality: Color, Race, and Racism in Urban Brazil. New Brunswick: Rutgers University Press.

Telles, Edward E. 2004. Race in Another America: The Significance of Skin Color in Brazil. Princeton: Princeton University Press.

Vigoya, Mara V. 2008. 'La sexualización de la raza y la racialización de la sexualidad en el contexto latinoamericano actual'. In Gloria Careaga (ed), Memorias del 1er. Encuentro Latinoamericano y del Caribe La sexualidad frente a la sociedad. México.

Wilmer, Franke. 1993. The Indigenous Voice in World Politics. Newbury Park: Sage.

\section{About the authors}

Sharon Stanley is a Professor of Political Science at the University of Memphis. She researches processes of racialization and the politics of race and racism throughout the Americas, with a particular emphasis on anti-blackness in Brazil and the United States. She is the author of two books: The French Enlightenment and the Emergence of Modern Cynicism (Cambridge University Press, 2012) and An Impossible Dream? Racial Integration in the United States (Oxford University Press, 2017). Her current project juxtaposes the discourse of post-racialism in the United States to the discourse of racial democracy in Brazil as exemplary strategies of the disavowal of racism. 
João Nackle Urt is Professor of International Relations at the Federal University of Grande Dourados (UFGD), Dourados, Brazil, and holds a Ph.D. degree in international relations from the University of Brasília (UnB). He was previously a professor at the Insikiran Institute for Indigenous Education at the Federal University of Roraima (UFRR), Boa Vista, Brazil, where he first engaged in research with Indigenous Peoples. He is currently Postdoctoral Visiting Researcher in the Graduate Programme in International Studies at the University of the Basque Country (UPV), Spain, with a project on Indigenous diplomacies.

Thiago Braz is a Ph.D. candidate at the Institute of International Relations of the Pontifical Catholic University of Rio de Janeiro (PUC-Rio), Brazil, with funding by the National Research Council (CNPq), holding a Master's in International Relations from the same institution. Graduated in (Public and Private) Management from Fluminense Federal University (UFF), Brazil, and Master's in International Business from the Institut d'Administration des Entreprises Aix-Marseille of Aix-Marseille University, France. Main areas of interest include: postcolonial, decolonial and counter-colonial studies; race, gender and class relations; international political sociology; international political economy; global finance; community/cooperative economics. 


\section{Triângulos Fatídicos no Brasil: Um Fórum sobre The Fateful Triangle: Race, Ethnicity, Nation, de Stuart Hall, Parte II}

Resumo: Stuart Hall, um acadêmico fundador da Escola de Birmingham de estudos culturais e eminente teórico de etnia, identidade e diferença na diáspora africana, bem como um dos principais analistas da política cultural dos anos Thatcher e pós-Thatcher, realizou as Palestras W. E. B. Du Bois na Universidade de Harvard em 1994. Nas palestras, publicadas após um atraso de quase um quarto de século como The Fateful Triangle: Race, Ethnicity, Nation (2017), Hall avança o argumento de que a raça, pelo menos nos contextos do Atlântico Norte, funciona como um 'significante escorregadio,' de modo que, mesmo depois que a noção de uma essência biológica para a raça tenha sido amplamente desacreditada, o raciocínio racial, no entanto, se renova ao essencializar outras características, como a diferença cultural. Substituindo a famosa díade de Michel Foucault com conhecimento-poder-diferença, Hall argumenta que pensar através do triângulo fatídico da raça, etnia e nação nos mostra como os sistemas discursivos tentam lidar com a diferença humana. Em 'Triângulos Fatídicos no Brasil', Parte II do Fórum da Contexto Internacional sobre The Fateful Triangle, três acadêmicos trabalham com e contra os argumentos de Hall do ponto de vista da política racial no Brasil. Sharon Stanley argumenta que a abordagem de Hall da identidade híbrida pode encontrar dificuldades no contexto brasileiro, onde os discursos de mistura racial têm, em nome da democracia racial, apoiado o racismo anti-negro. João Nackle Urt investiga as conturbadas histórias de 'raça,' 'etnia' e 'nação' em referência aos povos indígenas, particularmente os índios brasileiros. Por fim, Thiago Braz mostra, a partir de uma perspectiva que se baseia em pensadores afro-brasileiros, que enfatizar a contingência no conceito de diáspora pode ignorar a miríade de maneiras pelas quais brasileiros afro-diaspóricos são marcados como negros e, portanto, sujeitos à violência e desigualdade. A Parte I do fórum - com contribuições de Donna Jones, Kevin Bruyneel e William Garcia - examina criticamente as promessas e potenciais problemas do trabalho de Hall no contexto da América do Norte e da Europa Ocidental, na esteira do \#BlackLivesMatter e Brexit.

Palavras-chave: Stuart Hall; raça e racismo; identidade étnica; diáspora; Afro-brasileiros; povos indígenas; política racial brasileira.

Received on 12 March 2019, and approved for publication on 25 March 2019. 